\title{
Mineral, protein and nitrate contents in leaves of Pereskia aculeata subjected to nitrogen fertilization ${ }^{1}$
}

\author{
Maria Regina de Miranda Souza ${ }^{2}$, Paulo Roberto Gomes Pereira ${ }^{3}$, \\ Ivan de Paiva Barbosa Magalhães ${ }^{3}$, Maria Aparecida Nogueira Sediyama², Sanzio Mollica Vidigal², \\ Cléverson Silva Ferreira Milagres ${ }^{3}$, Maria Cristina Baracat-Pereira ${ }^{3}$
}

\section{ABSTRACT}

Considering that nitrogen is directly related to leaf protein content, the nitrogen fertilization in Pereskia aculeata plants may affect the protein content and increase its nutritional potential. This study aimed at assessing the effect of nitrogen fertilization on mineral, protein and nitrate contents, as well as the yield of $P$. aculeata leaves. A randomized blocks design was used, with three replications and five treatments, consisting of increasing topdressing nitrogen doses $\left(0-400 \mathrm{~kg} \mathrm{ha}^{-1}\right)$, in soil with organic matter content of 4.0 dag kg-1. Three harvests were performed for leaf analysis. No significant effect was observed for mineral and protein content or leaf fresh mass yield. The mean values for mineral composition were: $3.52 \mathrm{dag} \mathrm{kg}^{-1}$ of $\mathrm{N}, 0.47 \mathrm{dag} \mathrm{kg}^{-1}$ of $\mathrm{P}, 4.65 \mathrm{dag} \mathrm{kg}^{-1}$ of $\mathrm{Ca}, 0.71 \mathrm{dag} \mathrm{kg}^{-1}$ of $\mathrm{Mg}, 0.25 \mathrm{dag} \mathrm{kg}^{-1}$ of S, $36.64 \mathrm{mg} \mathrm{kg}^{-1}$ of $\mathrm{Zn}$ and $174.13 \mathrm{mg} \mathrm{kg}^{-1}$ of Fe. The mean content for protein was $21.86 \%$ and the leaf fresh mass yield was $0.971 \mathrm{~kg} \mathrm{plant}^{-1}$. K levels decreased from $50 \mathrm{~kg} \mathrm{ha}^{-1}$ of $\mathrm{N}$. Nitrate increased linearly with the nitrogen fertilization, reaching a maximum value of $78.2 \mathrm{mg} \mathrm{kg}^{-1}$ of fresh mass, well below the health risk threshold. It was concluded that a soil with high organic matter content does not require nitrogen fertilization. However, doses up to $400 \mathrm{~kg} \mathrm{ha}^{-1}$ of nitrogen ensure adequate leaf yield and protein and mineral contents within the desired range for the species, being a food rich in proteins, iron and calcium.

KEY-WORDS: Pereskia aculeata Mill.; non-conventional vegetable; plant nutrition.

\section{INTRODUCTION}

Pereskia aculeata Mill., also known as Barbados gooseberry, is a tropical plant from the Cactaceae family with scientifically proven nutritional and medicinal properties (Almeida Filho \& Cambraia 1974, Dayrell 1977, Takeitti et al.

\section{RESUMO}

Teores de minerais, proteína e nitrato em folhas de ora-pro-nobis submetido a adubação nitrogenada

Considerando-se que o nitrogênio está diretamente relacionado ao teor de proteína das folhas, a adubação nitrogenada de plantas de ora-pro-nobis pode influenciar no teor de proteína e aumentar o seu potencial nutritivo. Objetivou-se avaliar o efeito de doses de $\mathrm{N}$ sobre teores de minerais, proteína e nitrato e na qualidade nutricional e produtividade de folhas de ora-pro-nobis. Utilizou-se delineamento em blocos casualizados, com três repetições e cinco tratamentos, composto por doses crescentes de $\mathrm{N}\left(0-400 \mathrm{~kg} \mathrm{ha}^{-1}\right)$ aplicadas em cobertura, em solo com teor de matéria orgânica de 4,0 dag kg-1. Foram realizadas três colheitas para a análise de folhas. Não houve efeito significativo do tratamento para os teores de minerais e proteínas, ou massa fresca de folhas. Os valores médios para a composição mineral foram: 3,52 dag kg-1 de N; 0,47 dag kg-1 de P; 4,65 dag kg-1 de Ca; 0,71 dag kg ${ }^{-1}$ de Mg; 0,25 dag kg-1 de S; 36,64 $\mathrm{mg} \mathrm{kg}^{-1}$ de Zn; e $174,13 \mathrm{mg} \mathrm{kg}^{-1} \mathrm{de} \mathrm{Fe}$. Amédia para o teor de proteínas foi de $21,86 \% \mathrm{e}$ para a produtividade da massa fresca de folhas de $0,971 \mathrm{~kg} \mathrm{planta}^{-1}$. Os teores de $\mathrm{K}$ decresceram a partir de $50 \mathrm{~kg} \mathrm{ha}^{-1} \mathrm{de}$. O nitrato aumentou linearmente com a fertilização com $\mathrm{N}$, atingindo valor máximo de $78,2 \mathrm{mg} \mathrm{kg}^{-1}$ de massa fresca, muito abaixo do limite de risco para a saúde. Conclui-se que, para solo com alto teor de matéria orgânica, não há necessidade de adubação nitrogenada. Contudo, o uso de doses de $\mathrm{N}$ de até $400 \mathrm{~kg} \mathrm{ha}^{-1}$ permite obter produtividade de folhas e teores de proteína e minerais nas faixas adequadas para a espécie, sendo o alimento rico em proteínas, ferro e cálcio.

PALAVRAS-CHAVE: Pereskia aculeata Mill.; hortaliça não convencional; nutrição de plantas.

2009, Almeida et al. 2014). It is a semi-woody plant, with long branches and spines in the leaf axils. For maintenance purposes, the leaves are harvested by pruning the branches every 60 to 90 days, depending on growth.

In Brazil, P. aculeata is found from Bahia to Rio Grande do Sul State. Its natural habitat is the

1. Manuscript received in Oct./2015 and accepted for publication in Feb./2016 (http://dx.doi.org/10.1590/1983-40632016v4637959).

2. Empresa de Pesquisa Agropecuária de Minas Gerais, Viçosa, MG, Brazil. E-mails: reginas.epamig@gmail.com, marians@epamig.ufv.br, sanziomv@epamig.br.

3. Universidade Federal de Viçosa, Viçosa, MG, Brazil.E-mails: ppereira@ufv.br, ivan.barbosa@ufv.br, cleverson.milagres@ufv.br, baracat@ufv.br. 
tropical forest, but it is also grown domestically in both rural and urban areas. The plants have significant growth potential, especially as climbing vines, since their branches can reach up to $10 \mathrm{~m}$ in length (Duarte \& Hayashi 2005).

In domestic settings, $P$. aculeata is grown primarily as a hedge or free-standing shrub. Its leaves are consumed as a vegetable, although its fruit is also edible. The leaves are tender, moderately fleshy, and valued for their unique flavor and functional characteristics (Takeiti et al. 2009), including high levels of protein and minerals, such as calcium and iron (Almeida Filho \& Cambraia 1974, Takeiti et al. 2009, Almeida et al. 2014), and mucilage (Lima Junior et al. 2013).

In academic circles, the species is known as a non-conventional vegetable, a name given to little-known vegetables with no established cultivation technology (Kinupp 2006, Brasil 2013). The consumption of $P$. aculeata can improve the nutritional status of the population and also the income of small-scale rural farmers in different regions of Brazil (Almeida \& Corrêa 2012), due to its potential to become a commercially cultivated plant (Queiroz et al. 2015)

Despite its significant potential, there is little technical information in terms of agronomy, and few studies have been developed with this species (Brasil 2013). Current data on its nutritional potential come from studies based on material taken from institutional gardens or private yards (Almeida Filho \& Cambraia 1974, Takeiti et al. 2009, Almeida \& Corrêa 2012). As such, new technologies are needed to establish cultivation systems for the species, particularly in relation to plant nutrition.

Correct fertilization is linked not only to obtaining greater food production with minimum energy input, but also to ensuring the biological quality of food produced. The knowledge of the strategies that species use under conditions of high and low nitrogen availability in the soil provides information on the use of this nutrient throughout the growth cycle (Cavatte et al. 2012). In addition to enabling the assessment of the plants nutritional status, quantifying total nitrogen and $\mathrm{N}-\mathrm{NO}_{3}$ in leaves provides an estimate of the biological quality of food based on leaf protein and nitrate content.

Fertilization is vital in the production of vegetables, since these plants are demanding in terms of management and nutrition. However, according to Kathounian (1994), P. aculeata is generally lowmaintenance from a fertilization standpoint, despite its high leaf protein content (Almeida et al. 2014). Some studies show a variation of approximately $40 \%$ in leaf protein levels, ranging from $17.4 \mathrm{~g} \mathrm{~kg}^{-1}$ (Almeida Filho \& Cambraia 1974) to $28.9 \mathrm{~g} \mathrm{~kg}^{-1}$ of dry matter (Almeida et al. 2014).

Abundance and leaf quality are the main requirements for leafy vegetables and include the provision of good mineral content (Oliveira et al. 2013), determining factors in achieving a good yield (Machado \& Silva 2004). Nitrogen (N) is a fundamental component of protein and its levels directly affect the plant growth. Low $\mathrm{N}$ content can limit plant growth, whereas its adequate availability can ensure high yields. On the other hand, excessive levels can compromise the quality of leafy vegetables due to nitrate accumulation and negative impacts on the environment (Cavatte et al. 2012). Although $\mathrm{N}$ in the soil may come from the mineralization of organic $\mathrm{N}$ or its fixation by bacteria, as seen in pulses, for most crops the primary means of addressing $\mathrm{N}$ deficiency is through fertilization (Bredmeier \& Mundstock 2000).

Concerning the quality and quantity of P. aculeata production, Kathounian (1994) reported that although the species can be grown in different types of soil, provided it is well drained, yield is higher in more fertile or fertilized soil, with broader and tender leaves.

The present study aimed at evaluating the effect of $\mathrm{N}$ application on mineral, protein and nitrate contents in Pereskia aculeata leaves.

\section{MATERIAL AND METHODS}

The experiment was conducted at the Universidade Federal de Viçosa, in Viçosa (20 45' 14'S, $42^{\circ} 52^{\prime} 53^{\prime}$ 'W and mean altitude of $648.74 \mathrm{~m}$ ), Minas Gerais State, Brazil, from February 2011 to April 2012. The climate is classified as Cwa, according to the Köppen classification system, with rain during the summer and a dry winter. The average annual rainfall and temperature are $1,200 \mathrm{~mm}$ and $19^{\circ} \mathrm{C}$, respectively.

The soil in the study area is classified as Red-Yellow Argisol (Ultisol), with the following characteristics in the $0-20 \mathrm{~cm}$ depth layer: $\mathrm{pH}\left(\mathrm{H}_{2} \mathrm{O}\right)=6.4 ; \mathrm{P}=100.7 \mathrm{mg} \mathrm{dm}^{-3} ; \mathrm{K}=160.0 \mathrm{mg} \mathrm{dm}^{-3}$; $\mathrm{Ca}^{+2}=5.0 \mathrm{cmol}_{\mathrm{c}} \mathrm{dm}^{-3} ; \mathrm{Mg}^{+2}=0.8 \mathrm{cmol}_{\mathrm{c}} \mathrm{dm}^{-3}$; 
$\mathrm{Al}^{+3}=0.0 \mathrm{cmol}_{\mathrm{c}} \mathrm{dm}^{-3} ; \mathrm{H}+\mathrm{Al}=3.63 \mathrm{cmol}_{\mathrm{c}} \mathrm{dm}^{-3}$; $\mathrm{SB}=6.21 \mathrm{cmol}_{\mathrm{c}} \mathrm{dm}^{-3} ; \mathrm{t}=6.21 \mathrm{cmol}_{\mathrm{c}} \mathrm{dm}^{-3} ; \mathrm{T}=$ $9.84 \mathrm{cmol} \mathrm{dm}^{-3} ; \mathrm{V}=63 \%$; organic matter $=4.0 \mathrm{dag} \mathrm{kg}^{-1}$; and remaining $\mathrm{P}=30.8 \mathrm{mg} \mathrm{L}^{-1}$.

A randomized blocks design was used, with three replications and five nitrogen fertilization treatments (urea) at the topdressing doses of $0 \mathrm{~kg} \mathrm{ha}^{-1}$, $50 \mathrm{~kg} \mathrm{ha}^{-1}, 100 \mathrm{~kg} \mathrm{ha}^{-1}, 200 \mathrm{~kg} \mathrm{ha}^{-1}$ and $400 \mathrm{~kg} \mathrm{ha}^{-1}$, at 146 and 219 days after planting (DAP). An aqueous solution containing different nitrogen concentrations was prepared for each application, in accordance with the relevant treatment. Thus, for the treatment corresponding to a $\mathrm{N}$ dose of $50 \mathrm{~kg} \mathrm{ha}^{-1}$, the solution prepared contained $5.55 \mathrm{~g}$ of urea diluted in $2.0 \mathrm{~L}$ of water and was applied to the entire study area. For the remaining treatments, solutions were prepared in relevant proportions.

Plants rooted from $20 \mathrm{~cm}$ long cuttings were transplanted at 45 DAP to beds $(1.0 \mathrm{~m}$ wide, $1.0 \mathrm{~m}$ long and $0.2 \mathrm{~m}$ deep). The beds were prepared after tilling and harrowing the soil and arranged in a line along the slope of the terrain, spaced $1 \mathrm{~m}$ apart. A plant was placed in the center of each bed, resulting in a spacing of $2.0 \mathrm{~m}$ between plants. When necessary, invasive plants were controlled by hoeing.

Three harvests were conducted (340 DAP, 373 DAP and 418 DAP) to assess yield and collect leaf samples for chemical analysis. At each harvest, three branches were collected from the cardinal points around the plant. Cuts were made from the fourth to fifth leaf of the last branch, about $10 \mathrm{~cm}$ above the bifurcation of the branches (Figure 1).

Next, the leaves were removed from the branches and weighed, constituting leaf fresh mass. For the purpose of protein and mineral composition analysis, leaves were taken from the middle section of the branches, that is, they were new and fully extended. The leaf fresh mass was weighed and dried in a forced air oven at $65^{\circ} \mathrm{C}$, until constant mass. The dry material was weighed to obtain the leaf dry mass, being ground and used in the chemical analysis of minerals. The characteristics evaluated were leaf dry mass, leaf mineral content ( $\mathrm{P}, \mathrm{K}, \mathrm{Ca}, \mathrm{Mg}, \mathrm{S}, \mathrm{Fe}$ and $\mathrm{Zn})$, ammonia content $\left(\mathrm{NH}_{4}^{+}\right)$and nitrate level in the dry matter $\left(\mathrm{NO}_{3}^{-}\right)$.

To determine the $\mathrm{N}_{-} \mathrm{NH}_{4}^{+}, \mathrm{N}_{-} \mathrm{NO}_{3}^{-}, \mathrm{P}, \mathrm{K}, \mathrm{Ca}$, $\mathrm{Mg}, \mathrm{S}, \mathrm{Fe}$ and $\mathrm{Zn}$ concentrations, nitric-perchloric acid digestion was carried out in digestion blocks, under controlled temperature conditions (Malavolta et al. 1997). The ammonia quantification was performed after sulfuric acid digestion using the Nessler method (Jackson 1958), and nitrate was quantified following the sulfosalicylic acid digestion (Cataldo et al. 1975). Values were added to provide total $\mathrm{N}$ concentrations (Carneiro et al. 2001) and converted into protein content by multiplying them by a correction factor of 6.25 (Gomes \& Oliveira 2012). $\mathrm{P}$ and $\mathrm{S}$ were determined by colorimetry, $\mathrm{K}$ by flame photometry, and $\mathrm{Ca}, \mathrm{Mg}, \mathrm{Zn}$ and $\mathrm{Fe}$ by atomic absorption spectroscopy (Malavolta et al. 1997). The results were used to compare the nutritional status of the plants and the nutritional potential of leaves for human consumption.

Nitrate levels in dry matter were converted into fresh matter values multiplying them by $1 / 100 \mathrm{x} \%$ dry matter, for comparison with the maximum levels of accumulated nitrate in food reported in the literature and established in accordance with international standards (WHO 2003).

In each harvest, all the branches were removed from the plant and weighed, with total fresh matter expressed in $\mathrm{kg}$. Three branches from each side of the plant were used to assess leaf yield. The leaves were removed and weighed separately to calculate the leaf to branch ratio, which was multiplied by the

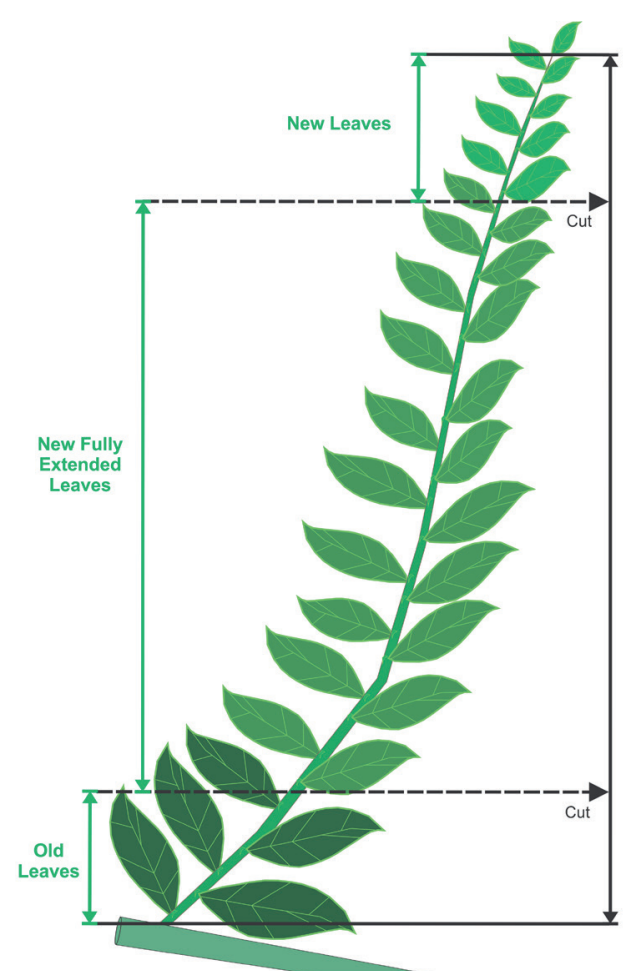

Figure 1. Diagram of a Pereskia aculeata branch showing the height of cuts and leaf growth stages. 
total fresh matter (leaves and branches) to obtain the leaf fresh mass. Thus, yield was calculated by adding the total fresh mass of the three harvests to obtain the total leaf fresh mass per plant. The data were subjected to analysis of variance via the $\mathrm{F}$ test at $5 \%$ and polynomial regression, using the Genes software (Cruz 2013).

\section{RESULTS AND DISCUSSION}

Nitrogen fertilization had no effect on leaf levels of N, P, Ca, Mg, S, Zn and Fe (Table 1).

$\mathrm{N}, \mathrm{P}, \mathrm{Ca}, \mathrm{Mg}$ and $\mathrm{S}$ contents in the P. aculeata leaves were within the appropriate range for several vegetables, including lettuce, kale and cabbage, and the $\mathrm{Mg}$ content was well above permissible levels for vegetables in general (Raij et al. 1996). K levels showed a significant effect for all the $\mathrm{N}$ doses applied (Figure 2).

Despite this decline, $\mathrm{K}$ levels remained within the appropriate range for vegetables (Raij et al. 1996). Diedrichs et al. (1984) reported positive responses to $\mathrm{N}$ fertilization and interaction between $\mathrm{N}$ and $\mathrm{K}$ in $P$. aculeata, and non-significant or negative responses to $\mathrm{P}$.
In addition, no effect was observed for total nitrogen, protein and leaf fresh mass for the $\mathrm{N}$ doses applied. The mean values obtained were $3.52 \mathrm{dag} \mathrm{kg}^{-1}$, $21.86 \%$ of protein in leaf dry mass and $0.97 \mathrm{~kg}$ of leaf fresh mass, respectively (Table 2).

Guimarães (2015) observed a linear decrease in the protein content of $P$. aculeata leaves in response to increasing doses of commercial organic compost.

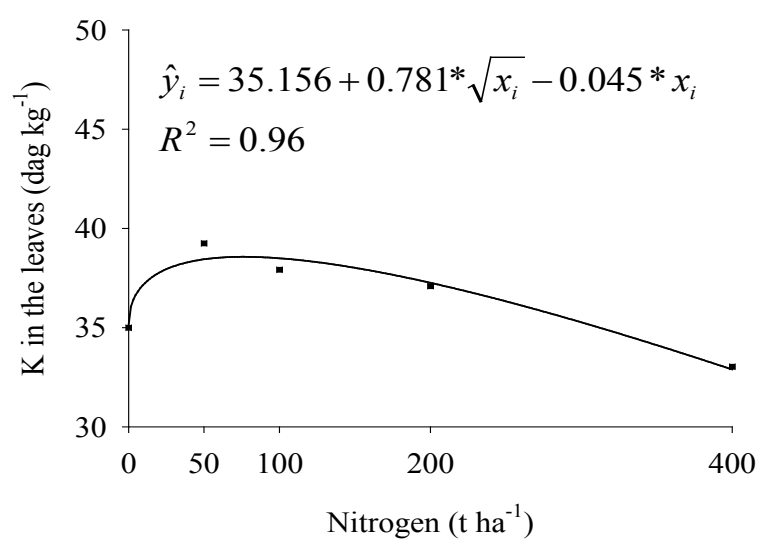

Figure 2 . K content in the dry matter of Pereskia aculeata leaves in response to increasing doses of nitrogen fertilizer (Viçosa, Minas Gerais State, Brazil, 2011/2012).

Table 1. Nutrient content in the dry matter of Pereskia aculeata leaves as a function of nitrogen fertilization (Viçosa, Minas Gerais State, Brazil, 2011/2012).

\begin{tabular}{cccccccc}
\hline Dose & $\mathrm{N}$ & $\mathrm{P}$ & $\mathrm{Ca}$ & $\mathrm{Mg}$ & $\mathrm{S}$ & $\mathrm{Zn}$ & $\mathrm{Fe}$ \\
\cline { 2 - 7 } $\mathrm{t} \mathrm{ha}^{-1}$ & & & dag kg-1 & & & & \\
\hline 0 & 3.587 & 0.560 & 4.496 & 0.647 & 0.249 & 34.984 & 199.721 \\
50 & 3.404 & 0.428 & 4.289 & 0.686 & 0.240 & 32.771 & 186.836 \\
100 & 3.335 & 0.460 & 4.872 & 0.732 & 0.264 & 37.432 & 148.138 \\
200 & 3.487 & 0.510 & 4.499 & 0.655 & 0.254 & 40.545 & 166.133 \\
400 & 3.761 & 0.402 & 5.071 & 0.841 & 0.253 & 37.455 & 169.844 \\
\hline Mean & 3.515 & 0.472 & 4.645 & 0.712 & 0.252 & 36.637 & 174.134 \\
\hline CV (\%) & 4.570 & 10.980 & 10.730 & 7.750 & 7.850 & 11.470 & 13.500 \\
\hline
\end{tabular}

Table 2. Concentrations of $\mathrm{N}$ and protein, $\mathrm{NO}_{3}$ - content in the dry and fresh matter, and leaf fresh matter of Pereskia aculeata (Viçosa, Minas Gerais State, Brazil, 2011/2012).

\begin{tabular}{rccccc}
\hline Dose & Total N & Protein in leaf dry mass & $\mathrm{NO}_{3}^{-}$dry matter & $\mathrm{NO}_{3}{ }^{-}$fresh matter & Fresh matter leaves \\
\hline $\mathrm{t} \mathrm{ha}^{-1}$ & dag kg-1 & $\%$ & $\mathrm{dag} \mathrm{kg}^{-1}$ & $\mathrm{mg} \mathrm{kg}^{-1}$ & $\mathrm{~kg} \mathrm{plant}^{-1}$ \\
\hline 0 & 3.587 & 22.320 & 0.019 & 34.796 & 1.359 \\
50 & 3.404 & 21.156 & 0.021 & 45.079 & 1.247 \\
100 & 3.335 & 20.759 & 0.017 & 32.454 & 0.903 \\
200 & 3.487 & 21.678 & 0.019 & 45.987 & 0.651 \\
400 & 3.761 & 23.360 & 0.031 & 78.196 & 0.698 \\
\hline Mean & 3.515 & 21.855 & 0.021 & 47.302 & 0.971 \\
\hline CV $(\%)$ & 4.570 & 4.603 & 17.947 & 21.197 & 29.404 \\
\hline
\end{tabular}


By contrast, the author recorded an increasing linear effect when chicken manure was used.

In the present study, the lack of a significant effect for total nitrogen, protein and fresh matter yield, as a function of nitrogen doses and harvest times, indicates that the $\mathrm{N}$ availability in the soil was above critical levels. This probably occurred because the soil studied has a high organic matter content ( $\left.4.0 \mathrm{dag} \mathrm{kg}^{-1}\right)$, and due to the low nitrogen requirement of these plants in relation to other vegetables. Similar results were reported by Andrade (2012), who studied the effect of irrigation associated with increasing proportions of organic compost in $P$. aculeata grown in pots and observed a quadratic effect of the proportions used on the protein content in the leaves, for all water depths tested. The soil organic matter contributed with $98 \%$ of organic $\mathrm{N}$ and therefore met the plant minimum nitrogen needs.

In the present study, there was a positive linear effect for the $\mathrm{NO}_{3}^{-}$content in the dry and fresh matter (Figure 3). The highest $\mathrm{NO}_{3}^{-}$levels in the leaf dry matter $\left(0.03 \mathrm{dag} \mathrm{kg}^{-1}\right)$ and fresh matter $\left(78.2 \mathrm{mg} \mathrm{kg}^{-1}\right)$ were obtained at the highest nitrogen dose applied (400 $\mathrm{kg} \mathrm{ha}^{-1}$ ) (Table 2). However, the $\mathrm{NO}_{3}{ }^{-}$concentrations obtained are considered low.

Krohn et al. (2003) analyzed nitrate levels in different lettuce cultivars (garden and cutting lettuce) and recorded values ranging 91-1,965 $\mathrm{mg} \mathrm{kg}^{-1}$. Beninni et al. (2002) observed levels below $1,500 \mathrm{mg} \mathrm{kg}^{-1}$ for conventionally grown lettuce. The reference values used for comparison are those established by the European Union, which vary 2,500-3,000 mg kg-1 for spinach and 3,500-4,500 $\mathrm{mg} \mathrm{kg}^{-1}$ for lettuce, based on fresh product. It is important to note that

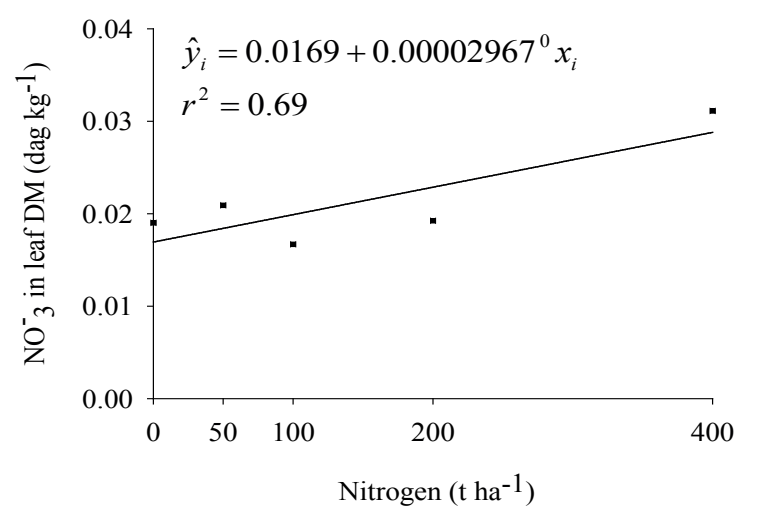

the maximum daily ingestion level for nitrate is $3.65 \mathrm{mg} \mathrm{kg}^{-1}$ of fresh weight (WHO 2003). As such, the value recorded for $P$. aculeata is within the required range for consumption.

The leaf fresh mass yield did not differ among treatments, with an average of $0.971 \mathrm{~kg}$ of fresh leaves per plant (Table 2). This yield is higher than that reported by Tofanelli \& Resende (2011), who obtained approximately $0.179 \mathrm{~kg}$ of fresh $P$. aculeata leaves per plant in three harvests, under similar growth conditions, fertilizing plants with $250 \mathrm{~g}$ of NPK (04-14-08) and $10 \mathrm{~kg}$ of cattle manure.

Guimarães (2015) applied increasing doses of commercial organic compost and obtained an increasing linear response for the fresh mass of plant shoots, with the highest yield ( $200 \mathrm{~g}$ ) recorded at the highest dose $\left(12 \mathrm{~kg} \mathrm{~m}^{-2}\right)$ after 20 days of cultivation. A quadratic effect was observed when chicken manure was used, which peaked at $120 \mathrm{~g}$ of fresh mass for the application of $4 \mathrm{~kg} \mathrm{~m}^{-2}$ of manure.

From an agronomic perspective, nutrient content is generally used to diagnose the nutritional status of plants, when compared to the critical level for the species studied. There are no reference values in the literature on critical levels for $P$. aculeate, in terms of the plant nutritional aspects. However, all the nutrients analyzed exhibited adequate levels in terms of average concentration in leaf dry matter, when compared to most plant species, as suggested by Malavolta et al. (1997) and Marschner (1998).

Concerning the nutritional properties of $P$. aculeata for human consumption, the mineral and protein contents recorded differ from those of the literature (Table 3).

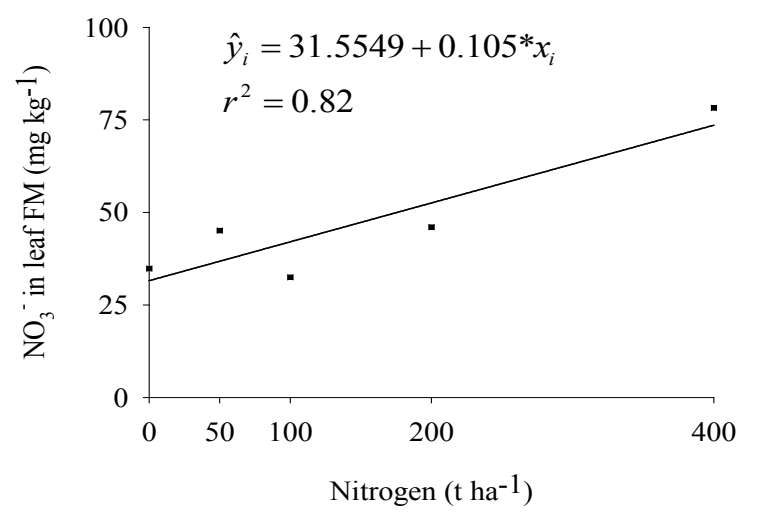

Figure 3. $\mathrm{NO}_{3}^{-}$content in the dry and fresh matter of Pereskia aculeata leaves in response to increasing doses of nitrogen fertilizer (Viçosa, Minas Gerais State, Brazil, 2011/2012). 
Table 3. Data from the literature consulted for contrasting the results obtained in the present study.

\begin{tabular}{|c|c|c|c|c|c|c|}
\hline \multirow{2}{*}{$\frac{\text { Composition }}{\text { Protein }\left(\mathrm{g} 100 \mathrm{~g}^{-1}\right)}$} & \multicolumn{2}{|c|}{$\begin{array}{l}\text { Almeida Filho \& Cambraia } \\
\text { (1974) }\end{array}$} & \multirow{2}{*}{$\begin{array}{c}\begin{array}{c}\text { Takeiti et al. } \\
(2009)\end{array} \\
28.40\end{array}$} & \multirow{2}{*}{$\begin{array}{l}\text { Oliveira et al. } \\
(2013) \\
-\end{array}$} & \multirow{2}{*}{$\begin{array}{c}\begin{array}{c}\text { Almeida et al. } \\
(2014)\end{array} \\
28.99 \pm 0.59\end{array}$} & \multirow{2}{*}{$\begin{array}{r}\begin{array}{c}\text { Results } \\
\text { obtained }\end{array} \\
21.86\end{array}$} \\
\hline & 17.40 & 25.50 & & & & \\
\hline $\mathrm{P}\left(\mathrm{mg} 100 \mathrm{~g}^{-1}\right)$ & $2,000.00$ & $1,800.00$ & 156.00 & 450.00 & $320.00 \pm 1.00$ & 472.00 \\
\hline $\mathrm{K}\left(\mathrm{mg} 100 \mathrm{~g}^{-1}\right)$ & - & - & $1,632.00$ & $3,740.00$ & $3,910.00 \pm 416.05$ & $3,644.00$ \\
\hline $\mathrm{Ca}\left(\mathrm{mg} 100 \mathrm{~g}^{-1}\right)$ & $3,400.00$ & $2,800.00$ & $3,420.00$ & $2,160.00$ & $1,346.67 \pm 30.55$ & $4,646.00$ \\
\hline $\operatorname{Mg}\left(\mathrm{mg} 100 \mathrm{~g}^{-1}\right)$ & $1,500.00$ & $1,200.00$ & $1,900.00$ & 680.00 & $586.67 \pm 5.77$ & 712.00 \\
\hline $\mathrm{S}\left(\mathrm{mg} 100 \mathrm{~g}^{-1}\right)$ & - & - & 270.00 & 360.00 & $583.33 \pm 25.17$ & 252.00 \\
\hline $\mathrm{Zn}\left(\mathrm{mg} 100 \mathrm{~g}^{-1}\right)$ & - & - & 26.70 & 3.30 & $7.30 \pm 0.06$ & 3.66 \\
\hline $\mathrm{Fe}\left(\mathrm{mg} 100 \mathrm{~g}^{-1}\right)$ & - & & 14.20 & 8.10 & $20.56 \pm 0.22$ & 17.41 \\
\hline Nitrate $\left(\mathrm{mg} \mathrm{kg}^{-1}\right)$ & - & - & - & & $16.20 \pm 0.37$ & 41.44 \\
\hline
\end{tabular}

Data from the studies analyzed refer to leaf levels found in individual plants, while data obtained in the present study (Table 3 ) are the mean of five treatments with three repetitions, with the respective coefficients of variation (Tables 1 and 2).

The overall average for protein was $21.86 \%$ in dry matter (Tables 2 and 3 ). This amount is below the values observed by Almeida et al. (2014) in Abaeté and Takeiti et al. (2009) in Belo Horizonte, and similar to that obtained by Almeida Filho \& Cambraia (1974) in Viçosa $(28.99 \pm 0.59,28.40$ and $17.4-25.5 \%$ of leaf dry matter, respectively), all located in the Minas Gerais State. The protein values obtained in this study (Table 2) varied 20.76-23.36 \% of dry matter, higher than that found by Almeida Filho \& Cambraia (1974) (17.4 \%) in Guiricema (Minas Gerais State). Although the authors do not mention the soil and climatic variables in which the plants were grown, these conditions, fertilization levels and plant origin, among others, probably influence the protein content in $P$. aculeata leaves.

The mean $\mathrm{P}$ and $\mathrm{K}$ contents measured in the present study (Table 3 ) are within the range of values reported in the literature for these nutrients (Takeiti et al. 2009, Oliveira et al. 2013, Almeida et al. 2014). The Ca level observed was higher than that recorded by the authors cited in Table 3, what suggests, from a mineral nutrition perspective, that nitrogen had a positive effect on Ca metabolism.

Given that $\mathrm{Ca}$ is an important mineral for health maintenance, $P$. aculeata could contribute to improve the nutritional status of people suffering from $\mathrm{Ca}$ deficiency, as recommended by specialists in human nutrition. Considering the population interviewed by Almeida \& Corrêa (2012), $12.5 \%$ highlighted the use of $P$. aculeata to prevent or treat osteoporosis, a disease related to Ca deficiency.

The leaf Fe content recorded in the present study was within the range of values reported in the literature (Table 3) (Almeida Filho \& Cambraia 1974, Takeiti et al. 2009, Almeida et al. 2014). The lowest Fe level observed in P. aculeata $(8.1 \%$ of dry matter) is higher than that found in spinach $(0.6 \%)$ and other foods commonly considered to be Fe sources, such as beef liver (5.8\%) and beetroot $(0.2 \%)$, and similar to that of beans $\left(8.0 \mathrm{mg} 100 \mathrm{~g}^{-1}\right)$ (TACO 2011).

Since $\mathrm{Fe}$ is necessary to prevent or combat anemia, it is important to identify and increase the diversity of available foods as a source of this mineral. According to the NRC (1989), the recommended daily Fe intake for adult men is $10 \mathrm{mg}$, what demonstrates the considerable contribution of $P$. aculeata to the diet.

Almeida \& Corrêa (2012) reported that $66.67 \%$ of the population studied from Abaeté admitted using $P$. aculeata to treat Fe deficiency anemia because they consider it "strong", that is, rich in Fe. Around $20-30 \%$ of the world adult population exhibit this type of anemia (Rodrigues \& Jorge 2010), whose primary cause is low Fe intake.

The $\mathrm{Zn}$ content in $P$. aculeata leaves was around $50 \%$ lower than that found by Almeida et al. (2014), but close to that observed by Takeiti et al. (2009).

These results confirm that the nutritional quality of $P$. aculeata leaves remains with the fertilizer used in the range of $0-400 \mathrm{~kg} \mathrm{ha}^{-1}$ of N. For being a perennial species, it is possible that, with frequent harvests and subsequent export of biomass, effects of the nitrogen fertilization on protein, minerals and yield may occur. 


\section{CONCLUSIONS}

1. Nitrogen doses up to $400 \mathrm{~kg} \mathrm{ha}^{-1}$ applied to the soil do not affect the $\mathrm{N}$ and protein levels in Pereskia aculeata leaves, in soil with a high organic matter content.

2. Concentrations of $\mathrm{N}, \mathrm{K}, \mathrm{P}, \mathrm{Ca}, \mathrm{Mg}, \mathrm{Zn}$ and $\mathrm{Fe}$ in P. aculeata plants fertilized with up to $400 \mathrm{~kg} \mathrm{ha}^{-1}$ of $\mathrm{N}$ are close to a critical level for most vegetables and adequate in terms of mineral nutrition and human consumption.

3. P. aculeata has a high nutritional quality, as it is rich in protein, $\mathrm{Ca}$ and $\mathrm{Fe}$.

4. The nitrate content $\left(78.2 \mathrm{mg} \mathrm{kg}^{-1}\right)$ of the $P$. aculeata leaf fresh mass, fertilized with up to $400 \mathrm{~kg} \mathrm{ha}^{-1}$ of $\mathrm{N}$, is within the parameters established by the World Health Organization and is therefore safe.

\section{ACKNOWLEDGMENTS}

To the Fundação de Amparo à Pesquisa do Estado de Minas Gerais (Fapemig) for funding research grants.

\section{REFERENCES}

ALMEIDA FILHO, J; CAMBRAIA, J. A. Study of the nutritive value of Pereskia aculeata Mill. protein source in human and animal consumption. Revista Ceres, Viçosa, v. 21, n. 1, p. 105-111, 1974.

ALMEIDA, M. E. F. et al. Chemical characterization of the non conventional vegetable known as ora-pro-nobis. Bioscience Journal, Uberlândia, v. 30, n. 3, p. 431-439, 2014.

ALMEIDA, M. E. F.; CORRÊA, A. D. Utilização de cactáceas do gênero Pereskia na alimentação humana em um município de Minas Gerais. Ciência Rural, Santa Maria, v. 42, n. 4, p. 751-756, 2012.

ANDRADE, R. R. de. Substrato e irrigação em orapro-nobis (Pereskia aculeata Mill.). 2012. 90 f. Tese (Doutorado em Ciências do Solo) - Universidade Estadual Paulista Júlio de Mesquita Filho, Jaboticabal, 2012.

BENINNI, E. R. Y. et al. Teor de nitrato em alface cultivada em sistemas hidropônico e convencional. Horticultura Brasileira, Brasília, DF, v. 20, n. 2, p. 183186, 2002.

BRASIL. Ministério da Agricultura, Pecuária e Abastecimento. Manual de hortaliças não convencionais. Brasília, DF: MAPA/ACS, 2013.
BREDMEIER, C.; MUNDSTOCK, C. M. Regulação da absorção e assimilação do nitrogênio nas plantas. Ciência Rural, Santa Maria, v. 30, n. 2, p. 365-372, 2000.

CARNEIRO, J. M. T.; ZAGATTO, E. A. G.; MATTOS, I. L.; MELO, D. Determinação indireta de N-total em plantas por espectrometria de absorção atômica com chama empregando uma minicoluna de $\mathrm{AgCl}(\mathrm{s})$. Scientia Agricola, Piracicaba, v. 58, n. 1, p. 151-155, 2001.

CATALDO, D. A. et al. Rapid calorimetric determination of nitrate in plant tissue by nitration of salicylic acid. Communications in Soil Plant Analysis, Wisconsin, v. 6, n. 1, p. 71-80, 1975.

CAVATTE, P. C. et al. The physiology of abiotic stresses. In: FRITSCHE-NETO, R.; BORÉM, A. Plant breeding for abiotic stress tolerance. Berlin: Springer-Verlag, 2012. p. 21-51.

CRUZ, C. D. GENES: a software package for analysis in experimental statistics and quantitative genetics. Acta Scientiarum Agronomy, Maringá, v. 35, n. 3, p. 271276, 2013.

DAYRELL, M. S. Extração e estudo do valor nutritivo de proteinas de folhas de ora-pro-nobis (Pereskia aculeata Mill). 1977. 106 f. Dissertação (Mestrado em Bioquímica e Imunologia) - Universidade Federal de Minas Gerais, Belo Horizonte, 1977.

DIEDRICHS, L. A. et al. Resposta do ora-pro-nobis (Pereskia aculeata Mill.) a diversos niveis de fertilizantes. In: CONGRESSO BRASILEIRO DE INICIAÇÃO CIENTÍFICA EM CIÊNCIAS AGRÁRIAS, 4., 1984, Taubaté. Anais... Taubaté: Universidade de Taubaté, 1984. p. 84.

DUARTE, M. R.; HAYASHI, S. S. Estudo anatômico de folha e ramo de Pereskia aculeata Mill. (Cactaceae). Revista Brasileira de Farmacognosia, Curitiba, v. 15, n. 2, p. 103-109, 2005.

GOMES, J. C.; OLIVEIRA, G. F. Análises fisico-químicas de alimentos. Viçosa: UFV, 2011.

GUIMARÃES, J. R. A. Produtividade e características fisico-químicas de ora-pro-nobis sob adubação orgânica. 2015. 59 f. Dissertação (Mestrado em Horticultura) Universidade Estadual Paulista Júlio de Mesquita Filho, Botucatu, 2015.

JACKSON, M. L. Soil chemical analysis. New Jersey: Prentice Hall, 1958.

KATHOUNiAN, C. A. Produção de alimentos para consumo doméstico no Paraná: caracterização e culturas alternativas. Londrina: Iapar, 1994.

KINUPP, V. F. Plantas alimentícias alternativas no Brasil: uma fonte complementar de alimento e renda. Revista Brasileira de Agroecologia, Porto Alegre, v. 1, n. 1, p. 333-336, 2006. 
KROHN, N. G. et al. Teores de nitrato em folhas de alface em função do horário de coleta e do tipo de folha amostrada. Horticultura Brasileira, Brasília, DF, v. 21, n. 2, p. 216-219, 2003.

LIMA JUNIOR, F. A. et al. Response surface methodology for optimization of the mucilage extraction process from Pereskia aculeata Miller. Food Hydrocolloids, Oxford, v. 33, n. 2, p. 38-47, 2013.

MACHADO, M. D.; SILVA, A. L. Distribuição de produtos provenientes da agricultura familiar: um estudo exploratório da produção de hortaliças. Revista de Administração da UFLA, Lavras, v. 6, n. 1, p. 67-80, 2004.

MALAVOLTA, E. et al. Avaliação do estado nutricional de plantas: princípios e aplicações. 2. ed. Piracicaba: Potafos, 1997.

MARSCHNER, H. Mineral nutrition of higher plant. 2. ed. New York: Academic Press, 1998.

NATIONAL RESEARCH COUNCIL (NRC). Recommended dietary allowances. 10. ed. Washington, DC: National Academic, 1989.

OLIVEIRA, D. C. S. et al. Composição mineral e teor de ácido ascórbico nas folhas de quatro espécies olerícolas não-convencionais. Horticultura Brasileira, Brasília, DF, v. 31, n. 3, p. 472-475, 2013.
QUEIROZ, C. R. A. A. et al. Growing Pereskia aculeata under intermittent irrigation according to levels of matric potential reduction. Pesquisa Agropecuária Tropical, Goiânia, v. 45, n. 1, p. 1-8, 2015.

RAIJ, B. V. et al. (Eds.). Recomendações de adubação e calagem para o Estado de São Paulo. 2. ed. rev. ampl. Campinas: IAC, 1996. (Boletim técnico, 100).

RODRIGUES, L. P.; JORGE, S. R. P. F. The iron deficiency in adult woman. Revista Brasileira de Hematologia e Hemoterapia, São Paulo, v. 32, supl. 2, p. 49-52, 2010.

TABELA BRASILEIRA DE COMPOSIÇÃO DE ALIMENTOS (TACO). 4. ed. Campinas: NEPA Unicamp, 2011.

TAKEITI, C. Y. et al. Nutritive evaluation of a nonconventional leafy vegetable (Pereskia aculeata Miller). International Journal of Food Sciences and Nutrition, Parma, v. 60, n. 1, p. 148-160, 2009.

TOFANELLI, M. B. D.; REZENDE, S. G. Sistemas de condução na produção de folhas de ora-pro-nobis. Pesquisa Agropecuária Tropical, Goiânia, v. 41, n. 3, p. 466-469, 2011.

WORLD HEALTH ORGANIZATION (WHO). Safety evaluation of certain food additives: fifty-ninth report of the joint FAO/WHO Committee on food additives. Geneva: WHO, 2003. 